\title{
A NEW LOCATION RECORD OF EUROPEAN POLECAT (Mustela putorius L.) FROM NORTHEASTERN FORESTS IN TURKEY
}

\section{NOVI LOKALITET PRIDOLASKA TVORA (Mustela putorius L.) U ŠUMSKIM PODRUČJIMA SJEVERNOISTOČNE TURSKE}

\author{
Ebubekir GÜNDOGDU*
}

\begin{abstract}
Summary
The present study deals with European Polecat Mustela putorius found at one locality (near the Kop River in Bayburt) on the region of Eastern Black Sea of Turkey. This species are new records for the Northeastern Anatolia and the city of Bayburt. European polecat was previously reported from the region of Marmara, Trakya and Western Black Sea. The morphological and distributional features of this species are presented.
\end{abstract}

KEY WORDS: European Polecat, biodiversity, distribution, new record, Northeastern Anatolian

\section{INTRODUCTION}

UVOD

Distributed throughout much of Europe, but absent from Ireland, European polecats declined in the early 20th century, reaching their lowest ebb by the $1950 \mathrm{~s}$ (MacDonald and Tattersall, 2001), and now Polecats range throughout Europe. European Polecat is widespread in the western Palearctic, east to the Ural Mountains of the Russian Federation; it is absent from Ireland, northern Scandinavia, much of the Balkans, much of the eastern Adriatic coast and occurs in Greece only marginally in the north. It is widespread in France, less so in the south-west and south-east (Berzins and Ruette 2014, Calenge et al. 2015), in mainland Spain (Grupo de carnívoros terrestres de la SECEM 2001, Virgós 2007), in Romania (IUCN, 2017) and in many other countries of its range. Since the year 2000 many distribution gaps in the Swiss Midlands and Jura have been filled and in the Grisons the species has expanded its range in the Vorderrhein Valley to almost the Oberalp Pass, and in the Vorderrhein Valley to the Via Mala area (Infofauna 2016).

In Europe, Western Polecat has been recorded from sea-level up to at least 1,600 $\mathrm{m}$ a.s.l. in Spain (Virgós 2007) and up to $1,400 \mathrm{~m}$ for the French Pyrenees and 1,500 $\mathrm{m}$ for the French Alps; previous statements of occurrence up to 2,000 $\mathrm{m}$ a.s.l. in France remain to be corroborated, although in Switzerland there are recent records at altitudes probably above 1900 a.s.l. (IUCN, 2017). The African populations occur from sea level to 2,400 m (Griffiths and Cuzin 2013).

European Polecat is listed as Least Concern in view of its wide distribution, large population and because it is unlikely to be declining at the rate required to qualify for listing in a threatened category or even as Near Threatened (IUCN, 2017)

* Assoc. Prof. Dr. Ebubekir GÜNDOGDU, Karadeniz Technical University, Faculty of Forestry, Department of Wildlife Ecology and Management, Trabzon, Turkey, ebubekirgundogdu@gmail.com 


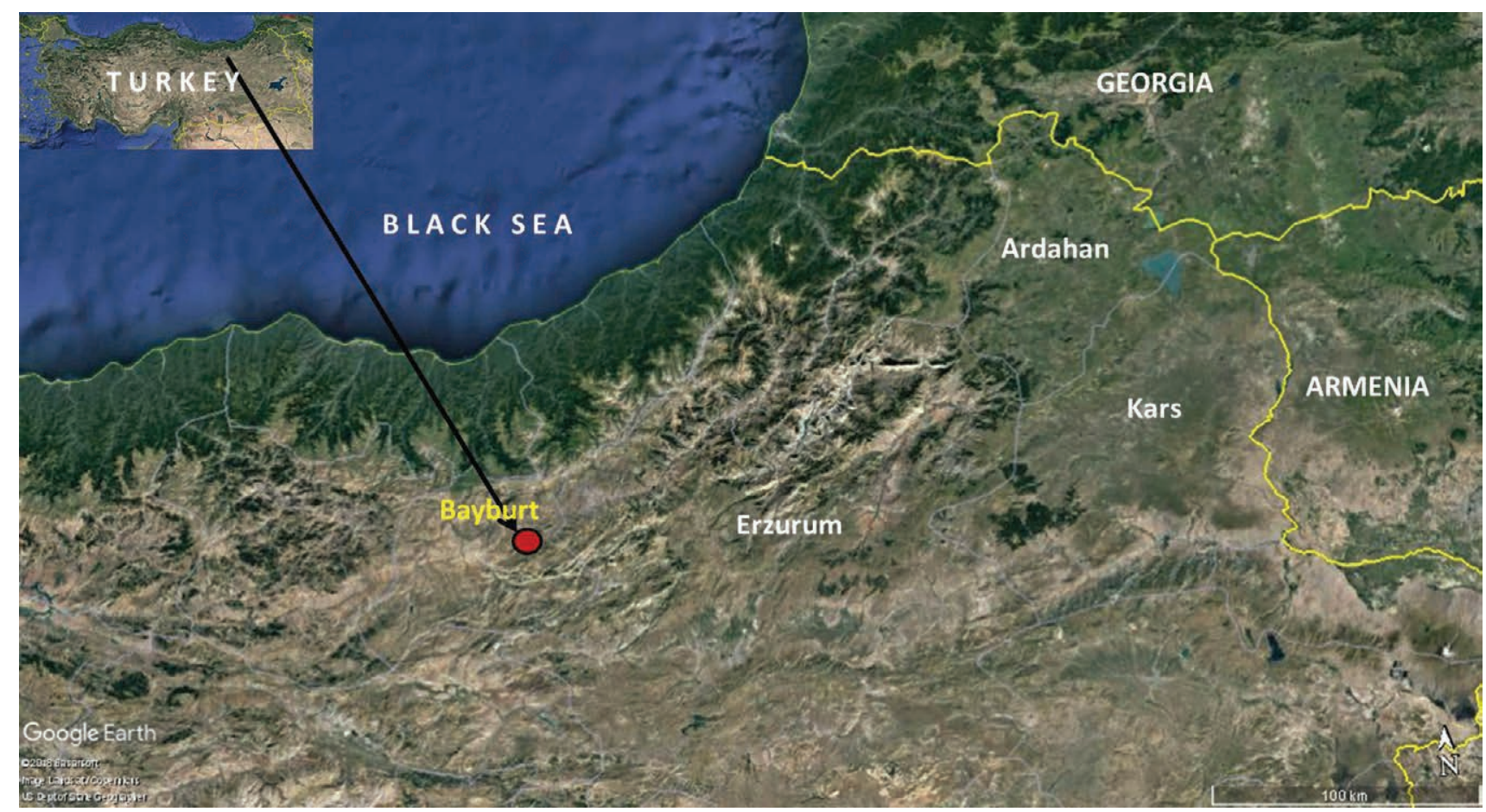

Figure 1. Map of the new location of European polecat

Slika 1. Mapa novog lokaliteta tvora

European polecat was previously reported from the region of Marmara, Trakya and Western Black Sea in Turkey (Demirsoy, 1996). The present study re-describes European Polecat species found at one locality on the Bayburt in Turkey that are new record for the Northeastern Anatoliafauna.

\section{MATERIALS AND METHODS MATERIJALI I METODE RADA}

A European Polecat individual was found dead on the road Bayburt to Erzurum near the Kop River $\left(40^{\circ} 12^{\prime} 33.84^{\prime \prime} \mathrm{N}\right.$ $40^{\circ} 16^{\prime} 25.22^{\prime \prime}$ E; $1590 \mathrm{~m}$.) located on the Northeastern Anatolia (Fig. 1). Dead individual was photographed on July $7^{\text {th, }}$ 2017 during a survey of the project Biodiversity of Bayburt and diagnosed (Fig. 2). For determination of the species, publications of Demirsoy, 1996 and MacDonald and Barrett, 2005 were used. According to Macdonald and Barett 2005, M. putorius has white at sides of nose, but dark on top of muzzle. The belly fur is yellowish with a glossy lustre. Flanks are lighter brown and the fringes of the ears pale. These morphological features overlap with the dead individual found.

\section{RESULTS}

REZULTATI

A species of Polecat, Mustela putorius Linnaeus, 1758 (Carnivora, Mustelidae) was recorded for the first time from Northeastern Turkey.
This species of previous years, in western Turkey (Marmara, Thrace and Western Black Sea) is situated record (Demirsoy, 1996). Bayburt is the most southern distribution area in Turkey of M. putorius. But despite being in the south, it is a cold region with an elevation of 1500 meters. In this case, the species may not be expected to spread in the southern regions of Turkey, but as a climate Bayburta similar Ardahan, Kars, Erzurum is thought to be possible to be encountered in provinces such as. In addition, this finding suggests that $\mathrm{M}$. putorius could spread in some parts of Georgia and Armenia with similar habitat and climate with Bayburt.

European polecat Mustela putorius has a weasel-like slender body, short legs and a broad head (www.animaldiversity.org). Males are much larger and heavier than females, but other than this size difference they share the same general appearance, with a buff to black colored coat (Environment agency, 1998) and a black face with a white mask around it (MacDonald and Tattersall, 2001). During winter the coat is thick, lustrous and glossy, but in summer it is thinner and appears somewhat faded (www.animaldiversity.org). European polecats are nocturnal, although activity levels peak at dusk. During the winter, they become less active and emerge during the day more than they would in summer. This opportunistic carnivore takes a great range of prey including rodents, amphibians, rabbits, eggs, birds, and insects (MacDonald, 2001). Individual polecats can take rabbits much larger than themselves (www.animaldiversity.org). 

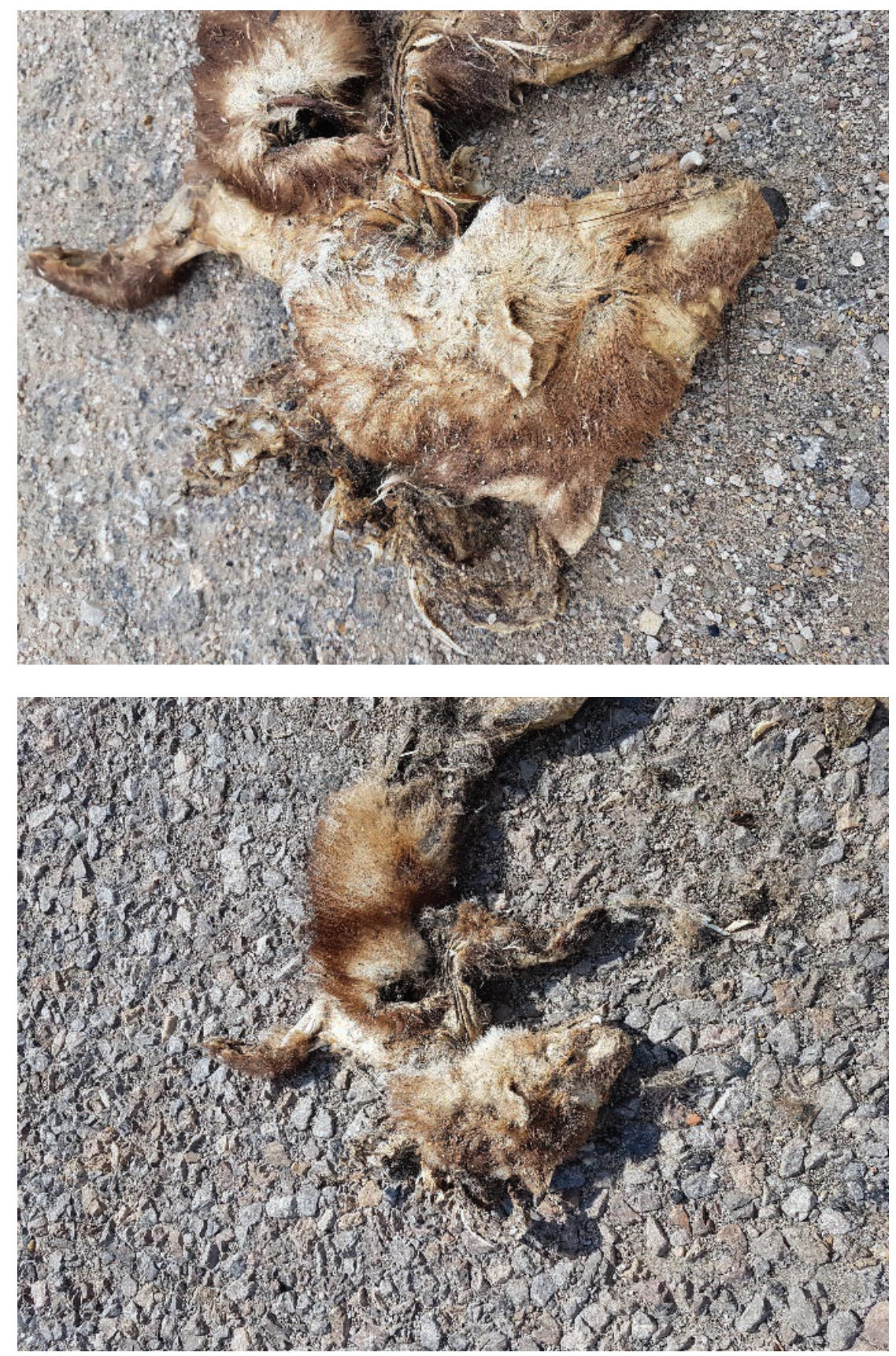

Figure 2. Dead European polecat on the road

Slika 2. Mrtav tvor

Material Examined: Steppe, Scrub, near the Kop River, Meseli Village, Bayburt, on the road Bayburt-Erzurum, 07 July 2017.

Distribution:Albania; Andorra; Austria; Belarus; Belgium; Bosnia and Herzegovina; Bulgaria; Croatia; Czech Republic; Denmark; Estonia; Finland; France; Germany; Gibraltar; Greece; Hungary; Italy; Latvia; Liechtenstein; Lithuania; Luxembourg; Macedonia, the former Yugoslav Republic of; Moldova; Montenegro; Netherlands; Norway; Poland; Portugal; Romania; Russian Federation; Serbia; Slovakia; Slovenia; Spain; Sweden; Switzerland; Turkey; Ukraine; United Kingdom (IUCN, 2017).

\section{DISCUSSION}

\section{RASPRAVA}

Martes are widely recorded in the research area but European polecat is very limited. Throughout the studies between 2016 and 2017, only one specimen of M. putorius was obtained in 2017. M. putorius has not been previously recorded in Bayburt (Demirsoy, 1996). Therefore, this species are new records for the Northeastern Anatolia and the city of Bayburt. The results of previous studies supported our findings regarding the morphological characters. 
In Turkey, having various geographical regions and different climates, the number of $\mathrm{M}$. putorius must be much higher than recorded so far. So, new studies should be conducted on this species intensively.

\section{ACKNOWLEDGEMENTS ZAHVALA}

This research supported by National Biological Diversity Inventory and Monitoring Project of Ministry of Forestry and Water Affairs. Also, the authors thank the Director, Bayburt DKMPGM personnel.

\section{REFERENCES}

\section{LITERATURA}

- Animal diversity web. 2017:http://animaldiversity.org/accounts/Mustela_putorius/

- Berzins, R. and Ruette, S. 2014: Status of the Polecat Mustela putorius (Linnaeus, 1758) in France and management implications. Munibe Monographs, Nature Series 3: pp.101-108

- Calenge, C., Chadoeuf, J., Giraud, C., Huet, S., Julliard, R., Monestiez, P. Piffady, J. Pinaud, D. and Ruette, S. 2015:The spatial distribution of Mustelidae in France. PLoS One10 (3 (e0121689)): pp. 1-18.
- Demirsoy, A. 1996: Türkiye Omurgalıları-Memeliler, Çevre Bakanlığı, Proje No: 90K 1000 90, Ankara. pp. 292

- Environment Agency. 1998: Species and Habitats Handbook. The Environment Agency, Bristol.

- Griffiths, H. and Cuzin, F. In press. Mustela putorius. In: J. S. Kingdon and M. Hoffmann (eds), The Mammals of Africa, Academic Press, Amsterdam, The Netherlands.

- Infofauna 2016: Mustela putorius Linnaeus, 1758. Available at: http://lepus.unine.ch/carto/index.php?nuesp=70752\&rivieres= on $\&$ lacs $=$ on $\&$ hillsh $=$ on $\&$ data $=$ on $\&$ year $=2000$. (Accessed: 5 March 2016).

- IUCN 2017:The IUCN Red List of Threatened Species. http:// dx.doi.org/10.2305/IUCN.UK.2016-1.RLTS. T41658A45214384.en

- MacDonald and Barrett. (2005) Mammals of Britain and Europe, Collins Field Guide.

- Macdonald, D. 2001:The New Encyclopedia of Mammals. Oxford University Press, Oxford.

- Macdonald, D.W. and Tattersall, F.T. 2001: Britain's mammalsthe challenge for conservation. The Wildlife Conservation Research Unit, Oxford University.

- Virgós, E. 2007: Mustela putorius, Linnaeus, 1758. In: Palomo, L.J., Gisbert, J. and Blanco J.C. (eds), Atlas y Libro Rojo de los mamíferos terrestres de España, pp. 294-298. Dirección General de Conservación de la Naturaleza, SECEM-SECEMU, Madrid, Spain.

\section{SAŽETAK}

Ovo istraživanje se bavi tvorom Mustela putoriu,s pronađenim na jednom lokalitetetu (blizu rijeke Kop u Bayburtu) u regiji Istočno Crno More u Turskoj. Ovo je novoutvrđena vrsta za sjevernoistočnu Anatoliju te grad Bayburt. Tvor je ranije primijećen u regiji Marmara i Zapadnom Crnom Moru. Prikazane su morfološke i distribucijske karakteristike ove vrste.

KLJUČNE RIJEČl: tvor, bioraznolikost, rasprostranjenost, novi nalaz, sjevernoistočna Anatolija 